\title{
VISITS OF J. VON RIBBENTROP TO THE USSR: PROTOCOL AND CULTURAL ASPECTS
}

\section{Zakharova O. Y.}

\section{INTRODUCTION}

The Munich Agreement of 1938 is a kind of milestone in the history of European states, many of which, including the USSR, were faced with a choice - peace or confrontation with Germany. The Soviet government announced its position in 1939, during visits to the USSR by German Foreign Minister J. von Ribbentrop.

The relevance of the study lies in the fact that in 1939 the foundations of the new world order were laid at the negotiations in Moscow, a "redrawing" of the map of Europe was made, taking into account the interests of Nazi Germany and the Soviet Union. Thus, the study of all the constituent parties of the negotiation process and subsequent events, whether political, protocol or cultural aspects, expands our ideas about one of the key events in the history of international relations.

The purpose of the research is to study the interrelation between the norms and traditions of the diplomatic protocol and etiquette with the priorities of foreign policy of states, using the example of relations between the USSR and Germany in 1939-1941.

The novelty of the work lies in the fact that the author undergoes a comprehensive study of the protocol components of Ribbentrop's visits to Moscow, which in themselves are an illustration of the moral, political and cultural life of the ruling Soviet elite.

The problems of cultural cooperation or rather the use of various cultural areas for propaganda purposes in the period 1939-1941 are considered in the work of A.V. Golubev and V.A. Nevezhin ${ }^{1}$, who study the impact of the visit of J. von Ribbentrop and the signed agreements on the development of cultural relations between Germany and the USSR.

In the presented study the author uses materials from the Archive of the Foreign Policy of the Russian Federation (AFP RF), many of which are introduced into the scientific circulation for the first time; in particular, excerpts from the Diary of the Head of the Protocol Department of the People's Commissariat of Foreign Affairs of the USSR (PCFA) V.N. Barkov on the reaction of diplomats to the speeches of V.M. Molotov, as well as the protocol aspects of the meeting of Ribbentrop in Moscow on August 23, 1939.

\footnotetext{
${ }^{1}$ Golubev A.V., Nevezhin V.A. The formation of the image of Soviet Russia in the surrounding world by means of cultural diplomacy. 1920s - first half of the 1940s. Moscow-St. Petersburg, 2016. P. 232.
} 


\section{Visit of J. von Ribbentrop in August 1939}

On August 23 at 13 o'clock at the Central Airport in Moscow German Foreign Minister J. von Ribbentrop was met by Deputy People's Commissar for Foreign Affairs V.P. Potemkin, Deputy People's Commissar of Internal Affairs V.N. Merkulov and other officials, as well as employees of the German embassy led by Schulenburg, the Italian ambassador Rosso accompanied by a military attaché, foreign journalists, Soviet cinema and photo reporters.

The airport balcony was decorated with flags. Two flags (Germany and the USSR) were installed on 2 flagpoles at the entrance to the airfield.

Schulenburg introduced V.P. Potemkin to Ribbentrop, then Rosso and all the persons of the Soviet side who were in the meeting delegation and the staff of the German embassy. Before getting into the car Ribbentrop greeted the representatives of the German colony who were not far from his car, in which the minister got in with Schulenburg. Ribbentrop's security chief took a seat near the driver ${ }^{2}$.

On the same day after negotiations in the Kremlin, in the office of the Minister of Foreign Affairs of the USSR Molotov, dinner was served for four people. At the beginning of the reception Stalin unexpectedly for those present, said a toast about Adolf Hitler as about a person especially revered by him.

At the end of the reception an episode quite peculiar of the Kremlin meeting took place. In response to Ribbentrop's request Stalin agreed that the Führer's personal photographer take several pictures (foreigners could not take pictures in the Kremlin). When Stalin and the guests were shot with glasses of Crimean champagne in their hands, Stalin said that this picture could not be published, but when the photographer gave the film to Stalin, he returned it, noting that he trusted the German guests and he was sure that the picture would not be published.

According to Ribbentrop this incident characterizes the atmosphere of his first visit to Moscow ${ }^{3}$.

On August 24 the German delegation leaved for Germany. Seeing off was like the reception. Deputy People's Commissar of Internal Affairs Merkulov did not attend the ceremony of seeing off ${ }^{4}$.

\section{The beginning of a propaganda company in the USSR}

Thus, the USSR violated the agreement with Poland and France of 1936 and entered into an alliance with Germany. The British and French military missions, which had been negotiating in Moscow for a long time, left the

\footnotetext{
${ }^{2}$ Diary of V.N. Barkov. Archive of the foreign policy of the Russian Federation. (AFP RF). F. 057. I. 19. F. 113. C. 1. P. 40.

${ }^{3}$ Ribbentrop J. Between London and Moscow. M., 1996. P. 143.

${ }^{4}$ Barkov V.N. Diary. 1939. AFP RF. F. 057. I. 19. F. 113. C. 1. P. 40. 
USSR. On August 25 the whole Diplomatic Corps with the exception of representatives of the English embassy and the ambassador of France, attended a private reception at the Japanese ambassador ${ }^{5}$. Diplomats are discussing protocol issues and Soviet officials are already beginning on August 27 to take an active part in the events of Soviet propaganda, which is doing everything possible to justify negotiations with Germany.

So on August 27 Voroshilov in his interview said that the reason for the disagreement in the Anglo-French negotiations was Poland, not Finland and the Baltic states. This statement was noted "with pleasure" in the Finnish mission ${ }^{6}$.

The next day (August 28) at the opening of the IV session of the Supreme Soviet of the USSR almost all diplomats accredited in Moscow were present, they then "talked" about the Soviet-German Non-Aggression Pact. Thus, the Turkish ambassador expressed the view that the Pact ensures the security of Turkey more than the Mutual Assistance Pact, about which Turkey had been negotiating with England (there was no British ambassador). The Afghan ambassador said his country favored the Soviet-German Pact. "Previously he (the Turkish ambassador - author) heard that Comrade Stalin was a great man, but only now $\langle\ldots\rangle$ he was personally convinced of what a great person was comrade Stalin"

The ambassadors of Estonia, Latvia, Finland and Sweden also spoke positively of the Pact. In their opinion it removes tensions in the Baltic Sea region. The Bulgarian envoy also approved the signed document, which stabilized the situation on the Balkan Peninsula.

The ambassador of Belgium said that he was "afraid" that Germany would intensify its aggressive tendencies in the West, making it difficult for Belgium to maintain its neutrality.

The Norwegian diplomat noted: "We like a bear sat in the den and waited for what would come of it" ${ }^{\prime 8}$.

In September preparations for the next visit of J. von Ribbentrop to Moscow began.

On September 25, 1939, Barkov received an adviser of the German embassy, who said that they intended to settle the visiting minister and his retinue in the building of the nearest Austrian mission and other persons - in the hotel. The adviser said that a direct Moscow-Berlin direct connection was needed (one telephone set should be in the embassy building, and the other in the Austrian mission). A request was also made for assistance in obtaining provisions in the grocery store No. 1 and No. 2 for guests.

\footnotetext{
${ }^{5}$ Barkov V.N. Diary. 1939. AFP RF. F. 057. I. 19. F. 113. C. 1. P. 41

${ }^{6}$ Barkov V.N. Diary. 1939. AFP RF. F. 057. I. 19. F. 113. C. 1. P. 42.

${ }^{7}$ Barkov V.N. Diary. 1939. AFP RF. F. 057. I. 19. F. 113. C. 1. P. 43.

${ }^{8}$ Barkov V.N. Diary. 1939. AFP RF. F. 057. I. 19. F. 113. C. 1. P. 43.
} 
On the same day ambassador von Schulenburg sent a telegram to Berlin, so that the German command in Warsaw arranged for the "transfer" of the employees of the Soviet embassy in Warsaw to the German command near Warsaw, guaranteeing them complete security, Barkov asked to give thanks to Mr. Ambassador for his initiative to "rescue" Warsaw Soviet citizens whose lives were in danger'.

On September 25 employees of the "former Polish embassy" left Moscow, "the Polish embassy no longer exists, just as the Polish ambassador does not exist", - Barkov writes in his diary ${ }^{10}$.

Here he reports that a request was received from Berlin whether the Czechoslovak mission was in Moscow, about the activities of the head of it, Fierlinger, information has got into the French press. "In Berlin, it is believed that the existence of a mission, to which Mr. Ambassador is incredulous, would not correspond to the real relations between the USSR and Germany". Barkov informed the embassy that there was no diplomatic representative of Czechoslovakia. The embassy representative "took note with satisfaction" of this message ${ }^{11}$.

In early August (August 3-6), 1940, the Lithuanian, Latvian, and Estonian Soviet Socialist Republics were accepted into the USSR.

At the end of September 1939 Ribbentrop flew to Moscow for the second time. As during his first visit he found "Stalin and Molotov gave him a pronounced friendly, almost cordial welcome" .

But if in August 1939 the Soviet side did not arrange celebrations to mark the visit of the German delegation, this time the guests from Germany received several "brilliant invitations".

In the Bolshoi Theater in honor of the German delegation was given "Swan Lake". "We sat in a large central box and admired the excellent musical performance and the unique charm of Russian ballet", - Ribbentrop recalled ${ }^{13}$.

On the occasion of the German delegation's stay in Moscow Stalin gave a big banquet in it honor, all members of the Politburo were invited to this banquet. Going up the stairs of the Grand Kremlin Palace, where the reception was arranged, Ribbentrop drew attention to the picture where Alexander II was depicted with peasants after the abolition of serfdom. "Along with other impressions it seemed to me a sign that in Stalin's Moscow there was an evolution of the thesis of the world revolution in a more conservative direction. The film "Peter the First" which was just on in Moscow, could also be interpreted in this direction".

\footnotetext{
${ }^{9}$ Barkov V.N. Conversation with Schulenburg. AFP RF. F. 057. I. 19. F. 113. C. 1. P. 61.

${ }^{10}$ Barkov V.N. Diary. AFP RF. 1939. F. 057. I. 19. F. 113. C. 1. P. 62.

${ }^{11}$ Barkov V.N. Diary. AFP RF. 1939. F. 057. I. 19. F. 113. C. 1. P. 62.

${ }_{12}^{12}$ Ribbentrop J. Between London and Moscow. M., 1996. P. 158.

${ }^{13}$ Ribbentrop J. Between London and Moscow. M., 1996. P. 160.
} 
According to Ribbentrop, Molotov spoke a lot at the banquet, whom Stalin (Ribbentrop sat next to him) incited to new speeches. Dishes struck with splendor and vodka was very strong. After Ribbentrop expressed his admiration for the superiority of "Russian throats over German", Stalin revealed to him the "secret": he drank only Crimean wine at the banquet, but it had the same color as vodka (the vodka was brown).

Throughout the evening Ribbentrop spoke amiably with members of the Politburo who approached him to clink glasses with him. He remembered especially Voroshilov and Kaganovich. The Soviet party elite made such a strong impression on the members of the German delegation that gauleiter of Danzig told Ribbentrop during the return flight that he felt just "among his old party comrades" $" 14$.

In his memoirs on his second visit to the USSR Ribbentrop writes not only about the performance at the Bolshoi Theater and the reception at the Kremlin, but also about how "the Baltic ministers with pale faces left the Kremlin. Shortly before Stalin informed them that his troops would enter their countries" $" 15$.

Confirmation of the Kremlin's new course aimed at rapprochement with Nazi Germany was Molotov's speech at a session of the Supreme Soviet of the USSR on October 31, 1939, where the head of the Soviet government declared: "It is possible to recognize or not to recognize the Nazi ideology, but it's not only pointless, but also criminal to wage war for the destruction of hitlerism" $"$.

In Barkov's record of October 31, 1939 there are reviews of members of the Diplomatic Corps on Molotov's report at an extraordinary session of the Supreme Council.

Barkov writes that "the Germans reacted very vividly to speech, exchanged cues and satisfied looks (von Schulenburg, Gilger, Schnurre, Genke, Kamp, Gefenes were present)" ${ }^{\prime \prime}$.

The first to leave the diplomatic box to the lobby was the English ambassador Seeds, who was in such a hurry that he awkwardly slammed the door. Von Schulenburg remarked: "A wonderful speech", and Gilger: "You can't say better".

The Turkish ambassador "was embarrassed, excited and red as a lobster". To the question of Barkov, how he assesses the Molotov's report regarding the Turkey, the ambassador replied: "I am satisfied with the report, an objective assessment". The Iranian ambassador found the report very important. According to him Turkey was in a difficult position, having concluded a pact of mutual assistance with England and France, which are at war. The

\footnotetext{
${ }^{14}$ Ribbentrop J. Between London and Moscow. M., 1996. P. 161.

${ }^{15}$ Ribbentrop J. Between London and Moscow. M., 1996. P. 172.

${ }^{16}$ Golubev A.V., Nevezhin V.A. The formation of the image of Soviet Russia in the surrounding world by means of cultural diplomacy. 1920s - first half of the 1940s. Moscow-St. Petersburg, 2016. P. 131.

${ }^{17}$ Barkov V.N. Diary. 1939. AFP RF. F. 057. I. 19. F. 113. C. 1. P. 72.
} 
ambassador considers Soviet proposals to Finland to be very modest. Lithuanian, Latvian and Estonian envoys approved the Molotov's report, while the Latvian envoy noted that "we were really very afraid of sovietization" $" 18$.

According to the Norwegian envoy the meeting of the Supreme Council impressed him with "great calm power". Barkov notes in his diary that Molotov's report made a very strong impression on the diplomats, who regarded it as an event of great political and historical importance ${ }^{19}$.

As for the protocol aspects, in spite of the generally accepted diplomatic traditions and conventions, the behavior of the representatives of the Diplomatic Corps was largely dependent on the foreign policy of their state.

The absence of the American ambassador, as well as the particular behavior of the ambassadors of England, Germany and the charge d'affaires of France, who met for the first time, did not go unnoticed. "It was interesting to follow the complex "maneuvers" that they did so as not to meet each other. They sat in different boxes. It became obvious that they would not maintain personal relations with each other", - said Barkov, the Head of the Protocol Department of the People's Commissariat of Foreign Affairs in his diary ${ }^{20}$.

During this period the employees of the German Embassy in Moscow were among the most active participants in diplomatic life of the capital of the USSR. On December 19 German diplomats were present at the reception at the All-Union Society for Cultural Relations (AUSCR), who were very pleased with the reception ${ }^{21}$.

German diplomats have fun at AUSCR and Estonian and Lithuanian envoys, as well as the secretary of the Latvian mission are seeking an appointment with Stalin to congratulate the leader on his 60th birthday ${ }^{22}$. All of them were recommended to send personal letters to I.V. Stalin, whom Hitler wishes in the congratulatory telegram on December 23 "good health" and "a happy future for the peoples of the friendly Soviet Union." A congratulatory telegram addressed to Stalin was also sent by J. von Ribbentrop. In a response from Stalin to Hitler and Ribbentrop it was emphasized that: "The friendship of the peoples of Germany and the Soviet Union, sealed with blood, has every reason to be long and lasting"23.

\section{Staging the opera "Valkyrie". The arrest of V.N. Barkov}

One of the vivid confirmations of the Kremlin's fidelity to the chosen course was the decision to stage at the the Bolshoi Theater of R. Wagner's

\footnotetext{
${ }^{18}$ Barkov V.N. Diary. 1939. AFP RF. F. 057. I. 19. F 113. C. 1. P. 72-73.

${ }^{19}$ Barkov V.N. Diary. 1939. AFP RF. F. 057. I. 19. F 113. C. 1. P. 73-74.

${ }^{20}$ Barkov V.N. Diary. 1939. AFP RF. F. 057. I. 19. F 113. C. 1. P. 74.

${ }^{21}$ Barkov V.N. Diary. 1939. AFP RF. F. 057. I. 19. F 113. C. 1. P. 88

${ }^{22}$ Barkov V.N. Diary. 1939. AFP RF. F. 057. I. 19. F 113. C. 1. P. 88-89.

${ }^{23}$ Golubev A.V., Nevezhin V.A. The formation of the image of Soviet Russia in the surrounding world by means of cultural diplomacy. 1920s - first half of the 1940s. Moscow-St. Petersburg, 2016. P. 131.
} 
opera "Valkyrie" by the outstanding Soviet film director S.M. Eisenstein, who openly expressed his anti-Nazi views ${ }^{24}$.

The premiere was scheduled for September 28, 1940 (on the anniversary of the Soviet-German friendship and border treaty). But on the day of the premiere of "Valkyrie" the opera of M.I. Glinka "Ivan Susanin" was on at the Bolshoi Theatre.

The director decided that the public would not see his production and would not hear Wagner's music, but Eisenstein's fears were in vain. The authorities were waiting for the right moment for the premiere of the opera.

On November 12-13, 1940 the Soviet delegation made an official visit to Berlin and Molotov held negotiations with Hitler and Ribbentrop. The "Valkyrie" premiere was planned as a kind of "greeting" to the delegation returning from Berlin. The "run" of the opera (dress rehearsal) took place on November 18, 1940 at the Bolshoi Theater. The performance was attended by the first deputy Head of the USSR Foreign Ministry A.Y. Vyshinsky. On November 21, the premiere of the opera was attended by representatives of the Soviet elite and the Diplomatic Corps. "Honorable places were reserved for the Germans, and in the center of the former royal box was the German ambassador to the USSR F.V. Schulenburg ${ }^{25}$.

German diplomats praised Eisenstein's staging as "sensational and very willful." After the Moscow premiere Goebbels allowed to put brief messages "in small print" in the political sections of the German press, thus the German side drew attention to the main event in the framework of German-Soviet cooperation, but "it was no longer possible to say it out loud" 26 .

The events in the Balkans in the spring of 1941 could not but affect the "language" of Soviet propaganda.

In the spring of 1941 the USSR began to take separate anti-German actions, one of which was the awarding of the Stalin Prize to the creators of the film "Alexander Nevsky", removed from a wide movie rental after signing the Molotov-Ribbentrop Pact. The film was on again in April 1941. The film was praised in an article by "Pravda" newspaper about Eisenstein's oeuvre.

The great director expressed his attitude to the Stalinist regime in the language of art, and first of all to the Stalinist repressions, in the movie "Ivan the Terrible" which is an outstanding work of world cinema.

The Stalinist repressions, which destroyed the best representatives of all segments of the population of Soviet society, did not bypass the People's Commissar of Foreign Affairs. In June 1941 Vladimir Nikolayevich Barkov

\footnotetext{
${ }^{24}$ Golubev A.V., Nevezhin V.A. The formation of the image of Soviet Russia in the surrounding world by means of cultural diplomacy. 1920s - first half of the 1940s. Moscow-St. Petersburg, 2016. P. 131.

${ }^{25}$ Golubev A.V., Nevezhin V.A. The formation of the image of Soviet Russia in the surrounding world by means of cultural diplomacy. 1920s - first half of the 1940s. Moscow-St. Petersburg, 2016. P. 136.

${ }^{26}$ Golubev A.V., Nevezhin V.A. The formation of the image of Soviet Russia in the surrounding world by means of cultural diplomacy. 1920s - first half of the 1940s. Moscow-St. Petersburg, 2016. P. 137.
} 
who was appointed head of the Protocol Department of the PCFA in 1935 was arrested.

The German side reported the leak of information from the Soviet-German negotiations and stated that it fully trusted the members of its team. Barkov had a habit of lingering after meetings and negotiations that were held at the highest level.

The People's Commissariat of Internal Affairs (PCIA) did not search for the guilty. A special commission sentenced V.N. Barkov to 20 years in prison. After spending 17 years in prison he was rehabilitated in 1958 as a victim of Stalinist repression.

V.N. Barkov like his predecessor D.T. Florinsky (arrested in 1934, repressed) did everything possible to "reconcile" the traditions of the European diplomatic protocol with the norms of Soviet ideology.

\section{CONCLUSIONS}

It was revealed that the protocol is not only a tool, but also a peculiar indicator of the priorities of the state's foreign policy, which was clearly manifested in the relations of the Soviet leadership with the German representatives in Moscow during the visit of $\mathrm{J}$. von Ribbentrop.

A few days after each of the minister's visits to the USSR, Molotov, in the presence of foreign diplomats, delivered a speech at sessions of the Supreme Soviet of the USSR, each of which testified to the cessation of the propaganda campaign against Germany, and, as a result, the beginning of a new stage in the cultural cooperation of the USSR and Germany, one of the vivid evidence of which was the production of S.M. Eisenstein's R. Wagner's opera "Valkyrie" on the stage of the Bolshoi Theater in Moscow.

The set of protocol norms during the visit itself and its cultural component confirmed the priorities of the Kremlin leaders in the field of international relations. The protocol is not only a political, but also a moral category. The norms of the protocol contain both ideology and social psychology of society, without an adequate interpretation of which it is difficult to understand the behavior of statesmen in a particular situation.

\section{SUMMARY}

In 1939 at the negotiations in Moscow with German Foreign Minister J. von Ribbentrop, the foundations of a new world order were laid and the map of Europe was "redrawn" taking into account the interests of Nazi Germany and the Soviet Union.

The purpose of the work is to study the dependence of the norms and traditions of the diplomatic protocol and etiquette on the priorities of foreign policy of states on the example of relations between the USSR and Germany in 1939-1941. 
For the first time the materials of the Archive of the Foreign Policy of the Russian Federation are introduced into the scientific circulation, namely excerpts from the Diary of the Head of the Protocol Department of the USSR People's Commissariat for Foreign Affairs V.N. Barkov about the meeting of J. von Ribbentrop at the Moscow airport, as well as the reaction of diplomats accredited in Moscow to V.M. Molotov's speeches in August and October 1939.

The cultural component of the visits is analyzed, from which a new stage in the history of Soviet-German cooperation began, which confirms the protocol of the meeting of the German Foreign Minister in Moscow, as well as the program of visits during which dinner was held in the Kremlin, a visit to the Bolshoi Theater, where the members of the German delegation had seats in the royal box, as well as a banquet in the Grand Kremlin Palace, which all members of the Politburo of the CPSU Central Committee were invited to.

It was revealed that the German embassy in Moscow was a kind of center for the diplomatic cultural life of the Soviet capital.

The protocol is not only a tool but also a peculiar indicator of the priorities of the state's foreign policy. The totality of protocol norms as a whole demonstrated the priorities of the Kremlin leaders in the field of international relations, the main direction of which during this period was friendship with Nazi Germany.

The Soviet elite made such a strong impression on the members of the delegation that one of them noticed during the return flight that he felt just among his party comrades.

One of the Kremlin's vivid confirmations of fidelity to the chosen course, aimed at establishing friendly relations with Germany, was the decision to stage on the stage of the Bolshoi Theater of R. Wagner's opera "Valkyrie" by the outstanding Soviet film director S. M. Eisenstein, who openly expressed his anti-Nazi views.

The premiere of the opera took place on November 21, which was a kind of "greeting" to the delegation arriving from Berlin after Molotov's negotiations with Hitler and Ribbentrop. In the Bolshoi Theater in the center of the royal box was Schulenburg, the German ambassador to the USSR.

V.N. Barkov, who was arrested in 1941, like his predecessor, D.T. Florinsky (arrested in 1934, was sentenced to death), did everything possible to "reconcile" the traditions of the European diplomatic protocol with the norms of Soviet ideology.

\section{REFERENCES}

1. Barkov V.N. Conversation with Schulenburg. 1939. Moscow. Archive of the foreign policy of the Russian Federation (AFP RF). F. 057. I. 19. F. 113. C. 1. P. 61 . 
2. Barkov V.N. Diary. 1939. Moscow. AFP RF. F. 057. I. 19. F. 113. C. 1. P. 40-43, 62, 69, 72-74.

3. Golubev A.V., Nevezhin V.A. The formation of the image of Soviet Russia in the surrounding world by means of cultural diplomacy. 1920s first half of the 1940s. Moscow-St. Petersburg, 2016. P. 131, 136, 232.

4. Ribbentrop J. Between London and Moscow. M., 1996. P. 143, 158, 160, $161,172$.

Information about author: Zakharova O. Y., Doctor of Historical Sciences, Professor, Independent Researcher 25, Galaganivska str., Priluki, Chernihiv region, 17500, Ukraine 